\title{
RESULTS OF TRIALS FOR THE CONTROL OF PORINA IN THE NELSON DISTRICT
}

\author{
D. C. F. PERrott \\ Entomology Division, D.S.I.R., Nelson
}

Summary

The results of three field trials investigating the effect of chemicals alternative to DDT showed that several materials were suitable replacements for the control of porina (Wiseana spp.). But it is suggested that a more critical approach to the use of these materials is needed and that this should be based on a better understanding of the species concerned in relation to their behaviour and to their response to insecticides.

\section{INTRODUCTION}

THE APPLICATION of DDT to pasture in New Zealand was, for all practical purposes, restricted to granular formulations by the Agricultural Chemicals (Insecticides) Regulations 1964 (Anon., 1964). The dry mix DDT/superphosphate preparations previously widely used had generally given satisfactory control of porina (Wiseana spp.) in addition to grass-grub (Costelytra zealandica (White)).

It was known that granular formulations of DDT were much less effective in controlling porina, probably because of their greatly reduced foliar contamination.

This paper describes three field trials conducted in the Nelson area with the object of providing data on the effective use of materials alternative to DDT superphosphate.

Trial Layout

\section{EXPERIMENTAL}

Randomized block layouts were used with a plot size of $15 \mathrm{ft} \times$ $15 \mathrm{ft}$ (approximately $1 / 200$ acre). No untreated areas were left between plots or blocks.

The area to be used for each trial was sampled prior to marking out, by taking spade square ( 7 in. $\times 7$ in.) samples on a $15 \mathrm{ft}$ square grid pattern, and extracting larvae by hand. The figures so obtained were used as a guide to the arrangement of plots in the manner described for grass-grub by Fenemore and Fleming (1964).

\section{Materials}

All insecticide formulations used were supplied by commercial organizations.

\section{ApPlication}

Spray treatments were applied by Oxford Precision Sprayer at 30 gal dilute spray per acre and operating pressure of $40 \mathrm{lb} / \mathrm{sq}$. in (All materials are given as active ingredient per acre.)

Granular formulations were applied by a precision granular applicator of the type described by Henderson (1962) and figured by Fenemore and Perrott (1965). Granules were diluted with suitable inert material to give rates equivalent to 60 to $100 \mathrm{lb}$ per acre to facilitate uniform application. Quantities were weighed and applied individually for each plot, and rates of application were adjusted so that the plot was covered in two directions at rightangles to each other. 


\section{Assessment of R̂Resultîs}

The effects of treatments were assessed primarily by sampling for larvae present in the plots at intervals after treatment. Samples consisted of cylindrical cores of $1 / 8$ sq. $\mathrm{ft}$ area or spade squares ( 7 in. $\times 7$ in.) taken to the depth of the larval tunnels (up to 10 to 12 in.). Larvae were sorted by hand and counted in the field.

Plots were also examined at intervals for possible pasture growth differences. When plot differences were apparent, plots were scored by several observers independently on an arbitrary scale of 0 to 5 .

\section{SPECIES}

The species of porina present on each of the three trial sites was $W$. cervinata only.

\section{SITE}

$$
\text { TRIAL } 1 \text { - APPLEBY }
$$

A flat area with the pasture consisting almost entirely of lucerne.

LAYOUT AND TREATMENTS

Nine replications were used. The mean pre-treatment larval population was 14.7 per sq. $\mathrm{ft}$, with a coefficient of variation of $55 \%$ (one spade square sample per plot).

The area was mown to a height of about 2 in. and raked clear one day before application of treatments. All treatments were applied on March 20,1964, under fine, practically calm conditions.

Details of treatments and the results of post-treatment sampling and estimation of growth response are given in Table 1.

A subsidiary trial was laid down at the same site to estimate the effect of a DDT formulation not previously available $(20 \%$ DDT granules in superphosphate). Details as for the main trial apply except that thirteen replications were used. Materials were applied on April 14, 1964, by a Scott lawn spreader and an equivalent weight of superphosphate was applied to control plots.

Details of treatments and the results of post-treatment sampling are given in Table 2.

SITE

$$
\text { TRIAL 2 - WAIMEA WEST }
$$

A flat area with a pasture of ryegrass and white clover.

\section{LAYOUT AND TREATMENTS}

Twelve replications were used. The mean pre-treatment larval population was 9.25 per sq. $\mathrm{ft}$, with a coefficient of variation of $49 \%$ (one spade square sample per plot)

Spray treatments were made on May 20, 1965, when the pasture was short ( $1 / 2$ to 1 in.) but damp with dew. As soon as these treatments were completed, 8 points of rain fell in about half an hour. The other treatments were therefore not then applied. A further 12 points of rain fell three days later.

On May 27 two samples were taken from each of the control and sprayed plots to give the following totals: diazinon, 53 ; trichlorphon, 59; control, 58.

On May 28 the sprayed plots were resprayed with the same treatments and the granule treatments applied.

Details of treatments and the results of post-treatment sampling are given in Table 3. 


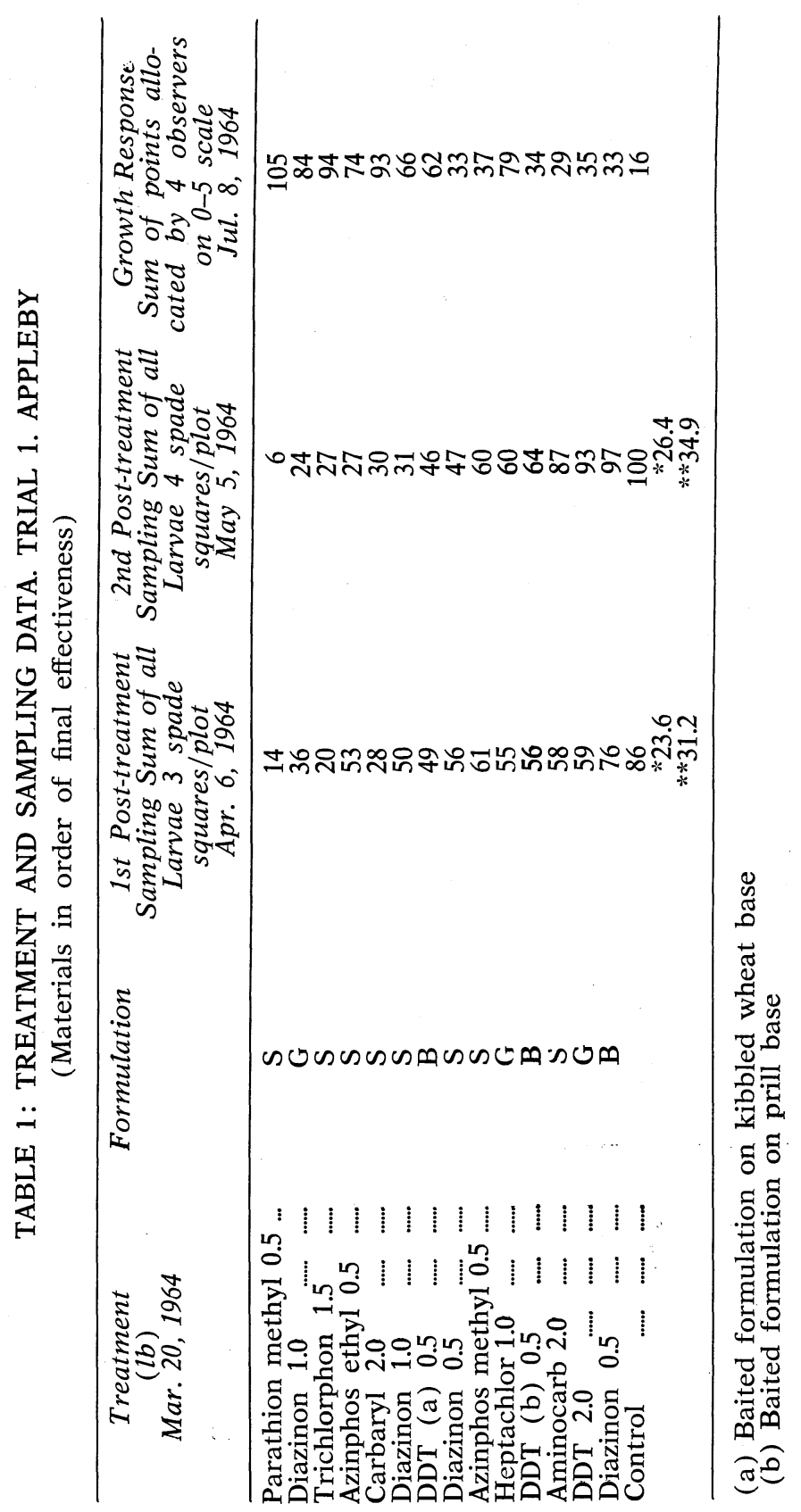


TABLE 2: TREATMENT AND SAMPLING DATA. TRIAL 1. APPLEBY

\begin{tabular}{|c|c|c|c|}
\hline $\begin{array}{c}\text { Treatment } \\
\quad(\mathrm{lb}) \\
\text { Apr. } 14,1964\end{array}$ & Formulation & $\begin{array}{l}\text { 1st Post-treat- } \\
\text { ment Sampling } \\
\text { Sum of all } \\
\text { Larvae } 4 \text { spade } \\
\text { squares/plot } \\
\text { May 5, 1964 }\end{array}$ & $\begin{array}{l}\text { 2nd Post-treat- } \\
\text { ment Sampling } \\
\text { Sum of all } \\
\text { Larvae } 4 \text { spade } \\
\text { squares/plot } \\
\text { Jun. 24, } 1964\end{array}$ \\
\hline \begin{tabular}{|lll} 
DDT 2.0 & $\ldots . . .$. & $\ldots . .$. \\
Control & $\ldots . .$. & $\ldots . . .$.
\end{tabular} & $\underline{G}$ & $\begin{array}{l}135 \\
134\end{array}$ & $\begin{array}{l}140 \\
155\end{array}$ \\
\hline
\end{tabular}

TABLE 3: TREATMENT AND SAMPLING DATA. TRIAL 2. WAIMEA WEST

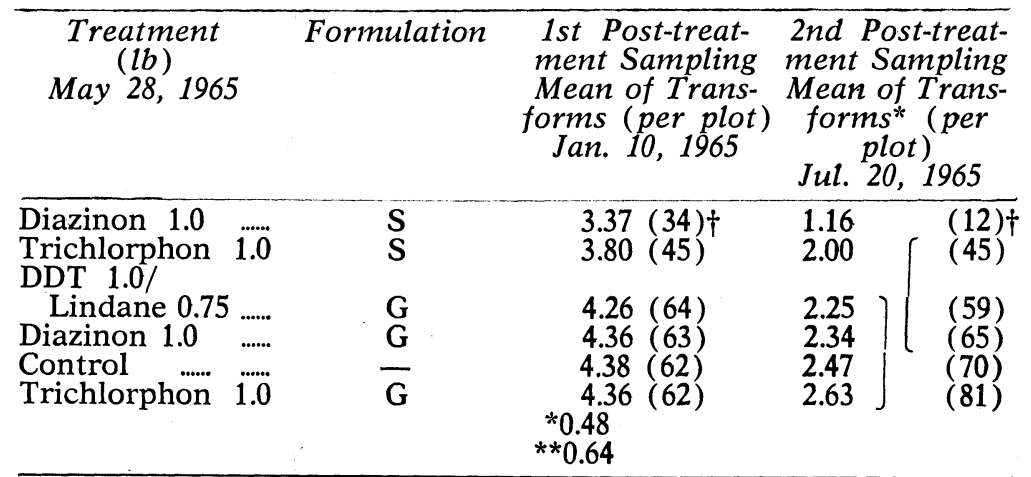

* Bars indicate non-significant groups of means using Duncan's test at $5 \%$ level or $t$ test at a high level of probability.

$\uparrow$ Sum of all larvae taken from 3 spade squares/plot.

\section{TRIAL 3 - RICHMOND}

The two previous trials were designed for separate and distinct purposes which were largely achieved (see Discussion). Nevertheless, it seemed that improvements in control might be obtained by more precise timing of treatments in relation to susceptibility of larvae to any particular toxicant and in relation to larval feeding habits.

Accordingly an experiment was designed in which estimates of susceptibility of larvae to the toxicants used and other measurements of larval growth and development would be made at the same regular intervals which separated successive applications of toxicants to field plots.

This trial is still in progress and Table 4 presents only part of the results which will become available for publication elsewhere.

TrIal SITE

A flat area with a pasture cover of ryegrass and white clover and some weed invasion.

The trial site was selected on the basis of the larval population of the generation preceding that against which treatments were directed. 
DDT (as prills) and diazinon (as coated calcite granules) werè each applied to give $1 \mathrm{lb}$ with treatments differing by 6-weekly intervals beginning with newly hatched larvae.

The results of field treatments to date are given in Table 4.

TABLE 4: TREATMENT AND SAMPLING DATA. TRIAL 3. APPLEBY

\begin{tabular}{|c|c|c|c|c|c|}
\hline & Sums of & all larvae & in 4 spade & squares & \\
\hline & Treated: & Dec. 7,19 & 5Jan. 17 & Feb. 28, & Apr. 12, \\
\hline & Sampled: & $\begin{array}{l}\text { Jan. } 24, \\
1966 \text { (a) }\end{array}$ & $\begin{array}{l}\text { Feb. 28, } \\
1966\end{array}$ & Apr. 12, & $\operatorname{May}_{1966} 25$, \\
\hline Control ..... & $\ldots . .$. & 34 & 60 & 49 & 33 \\
\hline DDT & .......... & 26 & 41 & 25 & 18 \\
\hline Diazinon .... & $\ldots$ & 1 & 12 & 6 & 1 \\
\hline
\end{tabular}

(a) Sums of larvae in six $1 / 8$ sq. ft samples/plot.

\section{DISCUSSION}

The basis of the three trials described here has shifted from the need to choose effective alternatives to DDT-superphosphate in the first trial to the point where emphasis is now on determining the most effective way to use these alternatives and to try to elucidate the reasons for the variations in results which occur.

\section{TRIAL 1}

In Trial 1 several insecticides produced significant reduction in larval numbers but only a few of them could be classed as having any practical application.

Several other interesting features emerged from the results of this first trial. Generally the more effective treatments were those applied as sprays which contrasts with the results of Helson et al. (1964) obtained at Hindon in the same year, where granular formulations (noticeably of diazinon) had been superior to sprays. This discrepancy led to the establishment of Trial 2 at Waimea West.

Also in Trial 1 the two DDT bait formulations both gave significant reductions in larval numbers (about $50 \%$.) which, although not commercially useful, suggests that this approach is worthy of greater consideration. The possibility of achieving control with low rates of cheap toxicants is particularly attractive in view of the financial return which can be expected from much of the land on which porina control is desirable.

Aminocarb and DDT prills which gave apparently significant reductions 17 days after treatment were not separable from control at the second post-treatment sampling. This acts as a reminder that statistical significance indicates only the degree of probability by which differences are real and do not arise by chance.

Since some materials in Trial 1 were expected to persist chemically into the succeeding year and it was conceivable that the influence of some others might remain, the trial was sampled again in 1965 when no larvae were found in any plot. This emphasizes the transient nature of porina infestations from season to season and warns that the persistent effect of a treatment should not be judged without control areas for comparison. 


\section{TRIAL 2}

This trial was laid down with the limited objective of comparing sprayable and granular formulations of the two then most widely used materials - i.e., diazinon and trichlorfon. A prill formulation of a DDT/lindane mixture which might be effective against both grass-grub and porina was also included. In spite of the maturity of larvae at the time of treatment (a pupa was found 13 days after treatment and general pasture recovery suggested that feeding was falling off), in each case spray formulations of the organophosphates were superior to granular formulations of the same material.

This trial has not been sampled in 1966 so that possible effects of the organochlorine mixture on a succeeding generation are not known.

TRIAL 3

The results presented in Table 4 clearly show a high degree of effect from diazinon applied against early instar larvae and that DDT prills, which were thought to have a possible use against early stages, did not give useful reductions. However, certain difficulties have beset the experiment of which this trial is a part. Owing to very dry field conditions and later oversowing, the pasture has been far from uniform for the application of toxicants and porina caterpillars have proved to be rather difficult subjects for precise toxicological work.

Whatever factors led to the sudden collapse of the Trial 1 population did not, in the same season, affect a nearby population at a site which was later used for Trial 3. This suggests that ecological investigations based on neighbouring populations undergoing the same weather pattern might reveal useful aids to control by management.

Alternatively, experiments carefully designed for this purpose would be informative. The papers of Martyn (1965) describe experiments of this very nature.

Other problems exist. This paper has not touched on the control of porina on land where two or more species are present whose stages do not coincide in time, neither have the economics of control been discussed except in passing.

These and other problems deserve the attention of research workers and formulators alike.

\section{ACKNOWLEDGEMENTS}

Thanks are due to Farm Chemicals Co., Henry H. York and Co. Ltd., Ivon Watkins-Dow Ltd. and the N.Z. Fertiliser Manufacturers' Research Association for the supply of materials, to the staff of Entomology Division, Nelson, for ideas and field work and to A. C. Glenday and Mrs V. I. Austen for statistical analysis of data.

\section{REFERENCES}

Anon., 1964: The Agricultural Chemicals (Insecticides) Regulations 1964. N.Z. Gaz., 1: 101.

Fenemore, P. G.; Fleming, Vivienne I., 1964: N.Z. J. agric. Res., 7: 219.

Fenemore, P. G.; Perrott, D. C. F., 1965: Ibid., 8: 832.

Helson, G. A. H.; Meeklah, F .A.; Darwin, R. K.; Robertson, T. G., 1964: Proc. 17th N.Z. Weed \& Pest Control Conf.: 165.

Henderson, C. F., 1962: J. econ. Ent., 55 (5): 663.

Martyn, E. J., 1965: Aust. J. Zool., 13: 801. 